\title{
Elizabeth Taylor and IIIness as a Negotiation of Femininity in Fan Magazines, 1960-1965
}

\author{
JULIE NAKAMA, University of Pittsburgh
}

\begin{abstract}
Fan magazines, primarily aimed at female audiences, provide a lens through which to analyze attitudes about female sexuality. In the 1960s, Elizabeth Taylor was o of the most popular stars in fan magazines. While coverage of her often focused on issues related to her marriages and children, another narrative about her health dominated headlines in the early part of the decade. Speculation about Taylor's illnesses stood in for a larger discourse about female appetites, ambition, and containment. This illness discourse gave fans graphic access to Taylor's body in ways that were gruesome rather than erotic as descriptions of her physical maladies reached ecstatic proportions. Public discourse about Taylor's health functioned in complex ways that affirmed and challenged ideologically conservative constructions of femininity and motherhood. This essay explores Taylor's appearances in fan magazines during the period 1960-1965 to examine the relationship between the star and notions of ambition, illness, and domesticity.
\end{abstract}

\section{KEYWORDS}

Celebrity, Fandom, Magazines, Stardom, Feminity

Since their earliest days, fan magazines have appealed to female spectators through content and advertising focused on stars, fashion, and beauty rituals (Slide 2010, 66). While these publications tell us much about the film industry and its products, they also tell us about ideologically dominant conceptions of femininity circulating in public discourse. In the 1950s and 1960s, femininity was closely aligned with notions of domesticity, which manifested in fan magazines through intense speculation about stars' marriages, divorces, and pregnancies. As with other women's magazines of the period, notions of feminine domesticity were linked to capitalism, patriotism, and Americanness in complex ways (Walker 2000, 16). During the midcentury, this constellation of meanings was part of a cultural landscape that was rapidly shifting. One way to analyze these shifts is to trace the treatment of a major star during this period to identify the cultural attitudes that accompanied her. This essay therefore considers the discourse surrounding Elizabeth Taylor in American fan magazines from 1960-1965 to understand changing public attitudes about modes of femininity during the period. Rather than provide a model for accepted feminine social behavior, like her one-time rival Debbie Reynolds, Taylor instead embodied feminine extremes. This essay argues that through narratives of illness, fan 
magazines imagined Taylor's body as a contested space in which conflicting notions of sexuality and reproduction played out through a sustained focus on Taylor's health and illness. Discourses about her physical state were tied to notions of female sexuality, domesticity, and modes of consumption. As Taylor became increasingly associated with her outsized appetites, narrative strategies used in fan magazines demonstrate the limits of public tolerance regarding female pleasure and the ways in which female sexuality and ambition were contained.

\section{Female Readerships and Public Discourses on Femininity in Women's Periodicals}

Tamar Jeffers McDonald notes that fan magazines were important to film studios because they engendered awareness of stars within fan communities leading up to, during, and beyond a star's appearance in a movie. As such, they also proved to be a valuable resource that enabled fans to revisit news and photos of stars in magazines as much as they wished, sustaining their interest until the star reemerged in another film or magazine spread (McDonald 2013, 35). ${ }^{1}$ Anthony Slide writes that the first fan magazine was The Motion Picture Story Magazine, published in February 1911. ${ }^{2}$ That same year Photoplay began its nearly seven-decade long run. Later magazines followed including Picture Play (1915-1941), Screenland (1920-1952), Screen Stories (1929-1978), Modern Screen (1930-1985), and Screen Stars (1944-1978). ${ }^{3}$ The 1920s and 1930s were the heyday of these publications and it is not coincidental that the establishment and popularity of the fan magazine was roughly concurrent with the establishment and growth of the Hollywood studio system. Film scholars have well established the relationship between the growth of the American film industry and the birth and proliferation of trade publications dedicated to film fans. ${ }^{4}$ The golden age of fan magazines is associated with James R. Quirk, who was an influential publisher at Photoplay (Slide 2010, 47). Under Quirk's influence, fan magazines established a symbiotic relationship with Hollywood that sought to promote and protect the industry. In addition to strictly cinematic fare, other publications existed that spoke to women's wider social interests. Modern Screen was among a crop of romance and fan magazines that printed gossip and advice columns, as well as feature-length articles, that were standard among fan magazines. Women were prominently involved in the writing and publishing of fan magazines and the publications operated with a female readership in mind. The intersection between women's interests, fan magazines, and the movie industry was therefore established early in the histories of both media.

\footnotetext{
${ }^{1}$ McDonald undertakes an historical study of Doris Day's appearance in fan magazines and their influence on her star image over the course of her career in Doris Day Confidential: Hollywood, Sex and Stardom.

${ }^{2}$ The Motion Picture Story Magazine became Motion Picture Magazine in 1914. It ceased publication in 1977.

${ }^{3}$ See Anthony Slide, Appendix 1, for a listing of fan magazines and their publishing runs.

${ }^{4}$ See the Mary Desjardins and Tamar Jeffers McDonald readings referenced here, also work on stars and fans by Shelley Stamp, Jane Gaines, Adrienne McLean, Marsha Orgeron, and Diana Anselmo-Sequeira.
} 
Fan magazines were aimed toward women with an emphasis on the 'imitative' female fan. Features taught readers how to dress, apply make-up, coif, eat, and furnish their homes like the stars. Reinforcing the connections among reader, star, and film made economic sense because, during the 1930s and 1940s, girls and women comprised one of the largest demographics of moviegoers (Slide 2010, 143). Fan magazines featured spreads of glamorous actresses promoting the latest fashions, and movie tie-ins provided a means to promote both fashion and stardom. As a result of such economic partnerships, fashion manufacturing and wholesaling increased dramatically in Los Angeles during the period. In his seminal essay on the relationship between Hollywood and female consumers, Charles Eckert notes that in the earliest days of the 1900s, Hollywood had one clothing manufacturer. By 1937 there were 130 members in the Associated Apparel Manufacturers of Los Angeles. In addition, the largest American departments stores all kept buyers in the city (Eckert 1978, 106). The relationship between Hollywood, female fans, and fashion was indisputable as magazines increasingly catered to the lives of young women who in turn seemed capable of influencing the growth of multiple industries centered around Hollywood. As film consumption was tied to a larger network of consumer spending patterns, the film industry was eager to protect its product through control over public discourse surrounding its films and stars, a task proved difficult.

Fan magazines continued to flourish through the 1950s with growing readerships; however, tensions between studio publicity departments and fan publications had begun to surface regarding the content of the magazines. In her study of the Association of Motion Picture Producers (AMPP), a trade association comprised of studio publicity and promotion directors that represented the interests of the studios to the fan magazine industry, Mary Desjardins demonstrates that by the mid-1940s studios were increasingly unhappy with salacious content of fan magazines. Particular articles that painted stars unfavorably, or outside of studio-sanctioned terms, were deemed 'destructive.' The AMPP reacted by suggesting that the organization 'present a "united front" toward the magazine editors and publishers,' perhaps by withdrawing advertising dollars from the publications (Desjardins 2014, 39). ${ }^{5}$ The AMPP continued to monitor the content of fan magazines and register complaints with their publishers for perceived breeches, but their efforts did not seem to have much effect. This may have been, in part, because in the early 1950s the film industry was itself changing. Anthony Slide writes that while fan magazines continued to remain largely celebratory, studio executives began to worry that the personal and in-depth content on stars' domestic lives was beginning to diminish the glamorous allure of the stars. Therefore, in 1953, MGM announced that it would no longer endorse articles about stars and their children but would instead push glamour pieces on the stars of the day. In conjunction with this move, magazine editors began to recognize that the age of their readerships

\footnotetext{
${ }^{5}$ Desjardins analyzed AMPP committee materials, housed at the Margaret Herrick Library, from the years 19451952. She argues that despite an early impulse to present a "united front," the AMPP did not seem to pursue that cause beyond their efforts waged during the late-1940s. Desjardins speculates that the incompleteness of the AMPP committee files leaves some questions unanswered and further suggests that the 1948 consent decree rulings may have diverted the committee's attention.
} 
was decreasing. As in many other segments of American popular culture, teenagers were beginning to form a powerful demographic. Publishers were eager to capture the vast and growing youth market. One way to capture this audience was to emphasize romance (Slide 2010, 170-172). Following Desjardins and Slide, it seems that content in fan magazines during the 1950s sought to depict stars in wholesome romantic relationships that were not necessarily domestic in nature, the details of which were designed to pique, but not dangerously stimulate, readers' interests.

The shifting content and demographic focus of fan magazines aligns with editorial changes made by women's magazines like McCall's and Redbook during the period as well. Particularly during the 1960s, women's magazines sought to move away from notions of family "togetherness" to instead emphasize the female reader as a woman with her own interests outside of the family. ${ }^{6}$ Putting fan magazines in conversation with women's magazines during the 1950s and 1960s can tell us something about larger public discourses about changing conceptions of femininity during the period because while fan magazines catered to film fans, one of the editors of Photoplay, Adele Whitely Fletcher, noted that the magazine was really a 'young woman's magazine' (Slide 2010, 70). Following Fletcher's claim, it is worth considering the intersections between fan magazines and women's magazines as a way to open possibilities for thinking about ideological constructions of femininity as they circulated among periodicals generally aimed toward female readerships.

Nancy Walker undertakes this work in her study of women's magazines at midcentury. Walker considers who and what was included, and excluded, from the readerships of women's magazines. She wonders to what extent the most popular women's magazines like McCall's, Redbook, Good Housekeeping, and Ladies Home Journal responded to political and social shifts and how they conceived of women's primary responsibilities. Walker argues that conceptions of homemaking and the home were tied to femininity, capitalism, patriotism, and Americanness in complex ways, and that women's magazines occupied a contested space within this matrix (2000, 16). Amid these contradictions, then, magazine content and advertising contained multiple meanings available to the women who read them. Walker suggests that rather than read women's magazines, and I would argue fan magazines, through the lenses of coercion or subversion it is more productive to view the magazines as cultural artifacts that negotiate some of the concerns and tensions present in women's lives at the midcentury. As artifacts of everyday life, magazine content and advertising represent one of the primary meeting spaces where

\footnotetext{
${ }^{6}$ For example, in 1954 McCall's magazine began a "togetherness" campaign to brand itself as a family-oriented periodical rather than one geared mainly towards women's interests, though the two were conflated. The "togetherness" campaign reflected a broader American ideology in the 1950s that valued organization, conformity, and group unity over individuality. This campaign ran through the early 1960s and by the time the magazine reached its peak readership of 8.5 million, it had rebranded itself as the "First Magazine for Women." In the 1970s it again revised its brand as "The Magazine for Suburban Women," reflecting the dominance of its suburban readership. See Sheila Silver (1976).
} 
women mingled with corporate strategies, consumer desires, ideological positioning, household labor, and material culture. With this approach in mind, I would like to look at the discourse surrounding Elizabeth Taylor in fan magazines during the period 1960-1965. Taylor offers an interesting case study because of her prominence in fan magazines over several decades that included a variety of shifting narratives about her personal and professional lives.

\section{Elizabeth Taylor and IIIness as Containment}

Elizabeth Taylor seemed to be the perfect star for magazine covers. She was a box-office draw who embodied a particular kind of American movie-star glamour. Taylor's titillating romantic adventures could be framed within conventional narratives about the institutions of marriage and family because Taylor was, after all, a dedicated practitioner. By the late 1950s Taylor had married three times and was on her way to a fourth. She had divorced twice, been widowed once, and given birth to two children. Her private life made fantastic copy, but part of Taylor's allure stemmed from her public enactment of a visceral, embodied form of femininity. In her analysis of Photoplay during the 1950s, Sumiko Higashi suggests that Elizabeth Taylor embodied romantic fantasies of stardom. Her extraordinary beauty coupled with her considerable appetites for food, drink, jewels, and marriage made her irresistible to fans and fan magazines. Higashi writes, 'she was a prima donna whose shopping sprees and sex scandals invited readers to fantasize on a baroque scale' $(2014,117)$. For Higashi, Taylor represented an extreme version of fifties consumer behavior most notedly rooted in courtship and marriage. Stories about Taylor routinely focused on her lavish lifestyle in contrast to her role as a dutiful mother and, sometimes, wife.

The cover story of the November 1956 issue of Motion Picture demonstrates how Taylor was initially positioned as a figure that balanced the demands of career and family deftly during the era. Taylor appears on the cover dressed in a demure high-necked knit sweater. Her gaze meets the camera through lowered eyelids and she looks alluring, but young and pretty. In the first two paragraphs of an article titled 'A Day in the Life of Liz,' by Howard Eisenberg, mentions Taylor's extravagant $\$ 150,000$ ranch home, a recent physical ailment, her separation from Michael Wilding, the expense of her latest film Raintree County, and her status at MGM. These elements of health, wealth, marriage, and career characterize coverage of Taylor in fan magazines as they did for many other stars. The article devotes a lengthy opening to describing Taylor's morning shower, noting that 'Barefoot Liz' is at her 'happiest when she's shoeless' (Eisenberg 1956, 66). The remaining pages describe Taylor's day in detail as Eisenberg invites the reader into Taylor's life to encourage an intimate exchange between fan and star. The article is laudatory and just hints at a fascination with Taylor's extravagant lifestyle. Over the course of the next ten years, coverage of Taylor would shift significantly from her professional life to an almost exclusive interest in her personal life. This move confirms the MGM directive to focus on romance rather than domesticity but also demonstrates an increasing public appetite for grittier content. As McDonald demonstrates, salacious headlines in fan magazines were nearly as old as 
fan magazines themselves, with most major magazines publishing sensational headlines by the mid- to late 1920s (McDonald 2016, 34). The difference in coverage about Taylor, however, has to do with the evolving fascination in her body as a site of gruesome display.

Fan magazines were interested in emphasizing the complex and often contradictory nature of Taylor's romantic life and the domestic aspect that often attended it. As Taylor continued to marry and divorce, Higashi notes that she also continued to give birth to or adopt children with each marriage, 'in keeping with the tenets of domestic ideology and the mandate of consumerism' $(2014,124)$. Taylor's embrace and flouting of domestic conventions mark her as an interesting figure by which to understand how fan magazines negotiated femininity during the period, particularly because they preferred Taylor to other major stars like Marilyn Monroe. During the 1950s, and until Monroe's death in 1962, Taylor was more often featured in fan magazines. One fan magazine publisher explained this phenomenon, suggesting that Taylor was more progressive, more independent, and that she 'didn't need public sympathy' (Slide 2010, 175). Stories from the 1959-1960 portray this independence as a love triangle between Taylor, Eddie Fisher, and Debbie Reynolds in which Taylor emerged victorious. For example, the cover of the March 1960 issue of Movie Mirror depicts Taylor and Reynolds facing off in profile with the headline 'When Liz and Debbie Meet Face to Face!' The photograph shows Taylor with a sideways glance as Reynolds looks at her face-on. In keeping with the conventions of fan magazine writing, the headline over-promises content and rather than report on an upcoming meeting between the two, Brianne Watson's article fantasizes about how one might occur. What is surprising is that the magazine was not shy about reporting on the financial benefit each actress reaped from the scandal. An article in the same issue reported that before the breakup of her marriage to Fisher, Reynolds television appearances were limited. Afterward, ABC paid Reynolds $\$ 1,000,000$, a share of ownership, and $\$ 300,000$ per show for a 'series of spectaculars' (Byrnes 1960, 35). In a move that is surprisingly transparent, the magazine reveals the economic benefit Reynolds and Taylor gained from the coverage.

By the end of 1960, coverage of Taylor shifted away from her rivalry with Reynolds and toward questions about a baby with Fisher, although the magazines continued to exploit the fractured domesticity of the Taylor-Fishers. Taylor represented a new kind of femininity defined by a negotiation between tradition and independence, fragility, and power. This dynamic was captured in an ongoing fascination with Taylor's physical problems through the 1960s as they related to child-birth and as they impacted her career. Her appearances in fan magazines during the decade are marked by questions about her health. The March 1960 cover of Motion Picture featured a close-up of Taylor with the headline, 'What the doctors can't tell Liz about her hidden illness.' The first page of the article features color photographs of Taylor in her 'glamour life,' dressed in jewels and an evening gown, positioned next to a still of Taylor in a Cat on a Hot Tin Roof (1958). The article wonders if Taylor would be able to handle the strain of her demanding roles. In the first line of the article, Bess Kerr describes one of many incidents in which an 
ambulance had been sent for Taylor. Kerr wonders why yet another illness had beset Taylor and tells readers that they must go back to the past to understand that Taylor is 'a woman who has experienced too much of good and evil not to break down' (1960, 70). Kerr proposes that Taylor's physical beauty is her great burden. For Kerr, Taylor is at odds with her body, unable to control it and profoundly victimized by it. Kerr describes Taylor as a woman bedeviled by her own flesh. Kerr writes, 'there is no resistance to illness - [there] is instead, almost a welcome for sickness' $(1960,71)$. Kerr describes Taylor as a woman predisposed to 'sickness' through a body unable to resist it and couples Taylor's physical weakness with her chronic pursuance of romantic relationships, suggesting that she suffered from a moral sickness as well. The article concludes that Liz's hidden illness is her desire for love, mainly, but also for professional success, money, motherhood, and excitement. Thus, the article explicitly makes the connection between Taylor's illnesses and her ambition. Kerr's article is an example of the ways in which progressive conceptions of femininity were still couched in terms that restrained unchecked ambition.

In a continuation of the illness narrative, the next month Taylor appeared on the cover of Movie Mirror. In an article a bit more lurid than Modern Screen's treatment of the actress, Taylor appears on the cover with Eddie Fisher, looking down at a piece of diamond jewelry in her hands. The headline promises to tell readers, 'Why Liz May Never Have Eddie's Baby!' The article, written by Connee Bates, poses Taylor as a figure deserving of pity and features a fullpage photo of Taylor holding her infant daughter Liza to her chest. It is accompanied by other photos of Taylor in full domestic mode as she lounges with her older children at a boardwalk or bottle-feeds her newborn from her hospital bed. The article contrasts these photos of family idyll with the rumor that giving birth to another child could kill Taylor. Bates tells readers that although they may not think of Taylor as a tragic figure, she is indeed one because her health is too delicate to risk giving Fisher a child of their own. Bates recounts Taylor's recent health problems and suggests that despite Taylor's most fervent desires, she should not become pregnant again. Bates worries: 'Liz is too delicate to have a normal delivery. And could she stand another Caesarean?' $(1960,18)$. Taylor's previous three Caesarean births were often cited as part of her difficult medical history.

Like other articles that narrativize Taylor's illnesses, Bates' article lays out the dominant ideological constructions of matrimony and motherhood before lamenting Taylor's inability to fulfill these roles in traditionally accepted ways. Bates writes that there isn't a 'mother more motherly than she' $(1960,64)$. Thus, the great tragedy for Taylor, and for the magazine's readers, is that she is unable to be a mother again, to be 'more motherly.' The conservative ideological positioning of the article is apparent in its efforts to explain why Taylor had not had a child with Fisher. Yet while the article offers explanations for Taylor, it positions her as a victim. She is not responsible for a childless marriage to Fisher, but rather suffers because of it. This move absolves Taylor and returns her to a more ideologically stable position of being ill rather than 
unwilling. It is interesting to note that the description of Taylor's desire to be "more motherly" hints at yet another form of excess, this one maternal in nature. Narratives about Taylor's body were often accompanied by worries about its resilience, which can be read more broadly as anxieties about female sexuality itself. The compulsion to pathologize Taylor's illness reflects a need in fan magazines to keep in check female pleasure and to frame resistance to motherhood as a malady rather than a desire.

In 1961 Taylor won the best actress award for Butterfield 8 and Hollywood was ready to forgive her for her role in the Fisher's divorce. That July, Screen Stories put Taylor on the cover, though styled in a way that recalled a younger version of herself. Her hair is cut short and worn in curls close to the head. She wears a low-cut red velvet dress with a sweetheart neckline. The lighting is soft and the image recalls a 1950s version of Taylor. It is significant that the magazine recuperated the image of a younger Taylor because it carried with it traditional notions of womanhood embedded in Taylor's dress, particularly via the cut of the neckline. Maureen Turim has analyzed the sweetheart neckline of women's formal gowns and its transformative effect. She argues that the neckline, which emerged alongside Dior's New Look in 1947, came to 'establish the transition to womanhood and marriage for women coming of age in the 1950s' $(1990,220)$.

As an example, Turim points to Taylor's transformation from teenager to young bride in Father of the Bride (1950). Taylor's wedding gown in the film has come to define the traditional wedding dress, thereby becoming a form that marks the transition between adolescence and maturity. Screen Stories' decision to put Taylor on the cover in a dress with a sweetheart neckline speaks to a more pervasive desire to recall a more innocent version of the Taylor persona. This is especially striking because Taylor won the Oscar for her portrayal of a call girl in 1961. These conflicting imaginings of Taylor underlie broader contradictory cultural attitudes about female sexuality in which the tension between innocence and experience poses problems. Inside the magazine, the article on Taylor was eager to detail 'How Hollywood Took Liz Back to its Heart!' The feature is accompanied by photos of Taylor as she actually looked in 1961 and the difference between the cover and feature photos points to the growing space between the idealized young actress and the aging, fleshy Taylor of the early 1960s. Of course, preoccupation with the actress's health problems persists. The article describes the night that Taylor won her Oscar as an act of near heroism. Mike Connolly writes that Taylor accepted the award in her 'illness-racked body' before slumping off the stage of the Santa Monica Civic Auditorium. Connolly's article revels in the graphic details of Taylor's physical state, which he had witnessed two weeks prior during a visit to her home. He writes, 'Her left ankle, still bandaged, had been punctured countless times for intravenous feedings, blood transfusions and antibiotic injections. Her neck was still bandaged, too, to cover that tracheotomy wound' $(1961,40)$. Three photographs accompany the text. One is of Taylor disembarking a plane in a wheelchair. The next is of Taylor seated next to Fisher at the Academy Awards ceremony, and in the last Taylor 
kisses her children after her win. The photographs capture the facets of her star persona during the early 1960s in their depiction of her illnesses, her career success, and her star-as-mother image. Connolly writes that Taylor's win was a triumph because the conservative members of the Academy had welcomed her back into their community despite her allegedly 'dissolute' lifestyle. Connolly considers Taylor's win to symbolize her return and reinstatement into Hollywood and here depictions of her health shift. Through illness, Taylor is restored to victory.

The status of Taylor's health continued to be a gossip item throughout the next few years. A short piece in the May 1962 issue of Modern Screen by Louella Parsons titled 'Elizabeth Taylor's Illness' illustrates the drama of Taylor's medical conditions. Parsons writes, 'After Liz was rushed to a hospital in Rome via ambulance, wild rumors exploded in all directions. Without even a word from her doctor, rumors were flashed around the world: That Elizabeth had suffered a serious throat hemorrhage and was bleeding profusely...' $(1962,15)$. As it turns out, Taylor reportedly had food poisoning. Another article in the same issue by Bethel Every further describes what 'really' happened in Rome the night of Taylor's hospitalization. It is accompanied by a black and white photograph of Taylor. She lies supine in a hospital bed with just the features of her face visible. The camera is positioned at the foot of the bed, foreshortening her figure in a way dramatically reminiscent of Renaissance paintings of the Christ figure. Indeed, the article nearly treats Taylor's bout of food poisoning as Biblical tragedy before breathing a sigh of relief that a stomach pump had not been necessary. The piece offers sensational details and speculation about the nature of Taylor's illness. Were bad oysters or American boiled beans to blame? As Eddie Fisher rushed to her side, was it true that Richard Burton also rushed in from Paris? Burton and Taylor had just made Cleopatra together and the May issue featured Taylor on the cover dressed in a costume from the film. The issue also featured what it declared were the first photos of Taylor's newly-adopted baby Maria. Thus, the issue expresses familiar concern with Taylor's body and health, graphic interest in her appetite for food, gossip about the men who rushed to her side, and a scoop on her new baby.

The stories that relish Taylor's illnesses betray a perverse interest in Taylor's physical failings, however they are gruesome in their detailing, not romantic. Taylor is not a wasting consumptive, rather discussions about her illnesses return to her surgeries and the invasive nature of the procedures. Her Caesarean procedures, "that" tracheotomy, and her back surgeries are all mentioned as if to suggest that underneath Taylor's beauty is a monstrous body that has been sliced and stitched back together many times over. This imagining of Taylor delights in examining her body from the inside out. Her womb, stomach, and spine are more closely examined in fan magazines than her other features besides, perhaps, her face. This fantasy of Taylor as a conflation of bravery, grotesqueness, and beauty is the version that has persisted, and that Andy Warhol elevated to pop art around the same period. The source image for Warhol's 1963 paintings, Silver Liz, came from a publicity still from BUtterfield 8. Warhol's fascination with Taylor was certainly linked to her stardom, but also perhaps her illnesses. Warhol's own 
biography included an affecting bout of childhood illness, the aftermath of which colored his own life. The image of Silver Liz features a print of Taylor with a wide gash of red painted over her lips and blue over her eyelids. Her image is rendered mask-like in a way that is simultaneously placid and garish. Warhol's Taylor is an extension of the Taylor that early 1960s gossip columnists crafted in fan magazines. Taylor is depicted as meeting the physical challenges of her suffering with great bravery but there is tremendous delight in detailing the grisly details of her wounds. The fascination with her pain and suffering in fan magazines borders on a sort of ecstatic pleasure that can be linked to other extremes that Taylor embodied including her bodily excesses and appetites.

By 1965 narratives of Taylor's illnesses were on the wane, though some version of the illness narrative would accompany her throughout her career as, indeed, she continued to experience various physical ailments. Her marriage to Fisher had ended and a new relationship with Richard Burton had begun. The Burton relationship came to define another period of Taylor's narrative in which passion played a recuperative role. In 1965 Photoplay imagined Taylor's sensual and volatile relationship with Richard Burton in an article titled 'My Nights with Richard,' which begins with a quote from Taylor: 'I never felt so alive before...I've never been so active on so little sleep' (Hoffman 1965, 41). The article is accompanied by a photo spread of the couple dining, kissing, and attending a Hollywood soiree before gathering the children for a Swiss vacation in Gstaad. Through her love affair with Burton, Taylor intimates that she was restored to health and vitality, once again linking her notions of her physical, professional, and moral health.

\section{Conclusion}

In the early 1960s, readerships for fan magazines declined dramatically, and by 1963 fan magazines that had once sold almost half a million copies per month now sold just over 150,000 (Slide 2010, 3). This was due, in part, to the dismantling of the Hollywood studio system a decade earlier as shifting industrial models of stardom affected fan magazines in numerous ways. Independent film producers and actors un-beholden to contracts no longer had any incentive to comply with studio wishes or maintain images dictated by studio executives. Performers became interested in promoting themselves, and some stars were more durable against scandal than others, with Taylor serving as an example of a star whose image was fairly resilient. More largely, shifting trends in fan magazines mirrored overall changes in the broader magazine industry. While fan magazines become more exploitive and rooted in tabloid-style journalism during the 1960s, tabloid magazines took up an interest in stars that changed the public discourse around stars and their stories. ${ }^{7}$ Rather than an industrially-sanctioned focus on stars, tabloids like

\footnotetext{
${ }^{7}$ Anne Helen Petersen writes that in the later part of the decade tabloids themselves turned away from gruesome, sensational stories toward personality-based journalism in which stories were crafted around interest in personal narratives and the private lives of public figures. For Petersen, this shift helped inaugurate a mode of thinking about celebrity in ways distinct from the publicity machine of the studio era.
} 
The Enquirer engaged in gossip, hearsay, informal truths, and storytelling about a myriad of public figures, reorienting the public's thinking about celebrity and its many forms. Scandalous gossip functioned in a progressive mode that challenged ideologically based status quo constructs in ways that were important to celebrities like Taylor. ${ }^{8}$

As fan magazines began to engage in more lurid gossip in the 1960s, they remained an important resource for the film industry because they got moviegoers into theater seats. They therefore continued to be an important tool for the film industry and a significant artifact within the cultural lives of women. As such, representations of Taylor in fan magazines from 1960-1965 speak to the ways in which conflicting attitudes about femininity were framed in the public sphere, particularly in relation to notions of domesticity and motherhood. Taylor proved to be a star that provoked scandal and could weather it well. Scandal enhanced her image. Questions about her health, marriages, and fitness for childbearing attended her entire career, yet Taylor's image coupled sexual vitality with physical fragility as a strategy to navigate these concerns. While insisting that she was rather traditionally devoted to marriage and family, narratives about Taylor simultaneously worked to undermine the stability of these institutions through a discourse of illness that tempered their ameliorative powers. This discourse functioned to establish Taylor's singularity. Through Taylor, fans could imagine femininity as a complex negotiation of pleasure, desire, and duty. The emphasis on Taylor's love of consumer luxuries equated femininity with an appetite for commodified goods; however, fan magazines managed these excesses through an emphasis on bodily toll as way a way to both celebrate and contain Taylor's extremes.

\footnotetext{
${ }^{8}$ For a discussion on the relationship between scandalous gossip and citizenry, see Petersen 2011.
} 


\section{References}

Bates, C. (1960) 'Why Liz May Never Have Eddie's Baby', Movie Mirror, April, 17-19; 64-65.

Byrnes, A. (1960) 'The Miracle of Debbie's Fan Mail', Movie Mirror, March, 35

Connolly, M. (1961) 'How Hollywood Took Liz Back to its Heart!', Screen Stories, July, 40-43; 72.

Desjardins, M. (2014) 'Fan Magazine Trouble': The AMPP, Studio Publicity Directors, and the Hollywood Press, 1945-1952', Film History, 26:3, 29-56

Dixon, D. (1966) 'Can a Doctor Save Liz Taylor's Marriage?', Modern Screen, August, 44-45; 60.

Dyer, R. (1986) Heavenly Bodies Film Stars and Society, 2ed, NY: Routledge.

Eckert, C. (1978, reprinted 1990) 'The Carole Lombard in Macy's Window', in J. Gaines and C. Herzog (eds), Fabrications Costume and the Female Body, NY: Routledge, pp. 100-121.

Eisenberg, H. (1956) 'A Day in the Life of Liz', Motion Picture, November, 50-51; 66-69.

Every, B. (1962) 'What Really Happened in Rome', Modern Screen, May, 30-33; 72-75.

Higashi, S. (2014) Stars, Fans, and Consumption in the 1950s: Reading Photoplay, NY: Palgrave McMillan.

Hoffman, J. (1965) 'My Nights with Richard', Photoplay, April, 41-47; 78-80.

Kerr, B. (1960) 'Her Hidden Illness', Motion Picture Magazine, March,19; 70-72.

Levin, M. (1970) Hollywood and the Great Fan Magazines, NY: Arbor House.

'Liz' Baby Plans' (1961) Modern Screen's Hollywood Yearbook, 4, 2-6.

Lysol Brand Advertisement (1956) Modern Screen, March, 24.

Mann, D. (1960) BUtterfield 8, MGM.

Mantegna, A. (c.1480) The Lamentation over the Dead Christ, Pinacoteca di Brera, Italy.

McDonald, T.J. (2013) Doris Day Confidential: Hollywood, Sex and Stardom, London: I.B. Tauris.

McDonald, T.J. (2016) 'Reviewing Reviewing the Fan Mags,' Film History, 28:4, 29-56

Nichols, M. (1966) Who's Afraid of Virginia Woolf, Warner Bros.

Parsons, L. (1962) 'Elizabeth Taylor's Illness', Modern Screen, May, 15

Petersen, A.H. (2011) 'Towards an Industrial History of Celebrity Gossip: The National Enquirer, People Magazine and "Personality Journalism" of the 1970s', Celebrity Studies, 2:2, 131-149

Silver, Sheila. 'Then and Now: Women's Roles in McCall's Magazine, 1964 and 1974,' College of Journalism, University of Maryland, Conference Presentation, The 59 th 
annual Meeting of the Association for Education in Journalism, 31 July - 04 August 1976

Slide, A. (2010) Inside the Hollywood Fan Magazine A History of Star Makers, Fabricators, and Gossip Mongers, Jackson: University Press of Mississippi

Turim, M. (1990) 'Designing Women: The Emergence of the New Sweetheart Line,' in J. Gaines and C. Herzog (eds), Fabrications Costume and the Female Body, NY:

Routledge, 212-228

Walker, N. (2000) Shaping Our Mothers' World American Women's Magazines, Jackson: University Press of Mississippi

Watson, B. (1960) 'When Liz and Debbie Meet Face to Face', Movie Mirror, March, 66

\section{Biography}

Julie Nakama, Ph.D is a Visiting Lecturer in the Film and Media Studies Program at the University of Pittsburgh. Her research interests include American film history, gender and industry studies, stardom, costume and fashion history, and material culture studies.

E-mail: jtn8@ pitt.edu 